\title{
HUBUNGAN STANDAR PELAYANAN ANTENATAL CARE (ANC) 10 T DENGAN KEPUASAN IBU HAMIL DI WILAYAH KERJA PUSKESMAS TLOGOSARI KULON KOTA SEMARANG
}

\author{
Kharisma Rakhmaha*); Hanifatur Rosyidah ${ }^{\mathrm{b}}$; Rr. Catur Leny Wulandaric \\ a,b, cFakultas Kedokteran Prodi Kebidanan; Universitas Islam Sultan Agung Semarang \\ Jalan Raya Kaligawe Km. 4 Po.Box 1054/SM Semarang 50112 - Indonesia
}

\begin{abstract}
Abstrak
Kota Semarang jumlah Angka Kematian Ibu (AKI) sebanyak 88,3 per 100.000 Kelahiran Hidup (KH) di tahun 2017. Penyebab kasus AKI yaitu adanya keterlambatan dalam deteksi kehamilan dan pelaksanaan ANC belum sesuai standar. Kualitas pelayanan yang baik dilakukan oleh tenaga kesehatan pastinya akan meningkatkan kepuasan masyarakat. Tujuan penelitian ini untuk mengetahui standar pelayanan ANC 10 T terhadap kepuasan ibu hamil di Puskesmas Tlogosari Kulon Kota Semarang. Jenis penelitian ini merupakan observasional analitik dengan pendekatan cross sectional. Pengambilan sampel dilaksanakan dengan menggunakan accidental sampling didapatkan sebanyak 55 ibu hamil TM III. Metode analisis data menggunakan uji descriptive stastictics frequencies dan uji chi-square. Hasil penelitian didapatkan bahwa standar pelayanan ANC $10 \mathrm{~T}$ sebagian besar dilakukan secara lengkap sesuai standar 10 T yaitu 43 ibu hamil (78,2 \%). Kepuasan ibu hamil pada waktu melakukan pemeriksaan ANC sebagian besar ibu hamil merasa puas dengan pelayanan yang diberikan oleh bidan yaitu 44 ibu hamil (80\%). Ada hubungan standar pelayanan ANC $10 \mathrm{~T}$ terhadap kepuasan ibu hamil. Kesimpulannya mayoritas pelayanan dilakukan sesuai standar dan ibu merasa puas.
\end{abstract}

Kata kunci: Angka kematian ibu, Standar pelayananan ANC 10 T, Kepuasan ibu hamil.

\begin{abstract}
[RELATIONSHIPS FOR $10 \mathrm{~T}$ Antenatal Care (ANC) SERVICE STANDARDS WITH PREGNANT MOTHER SATISFACTION IN THE TLOGOSARI KULON PUSKESMAS PUSKESMAS AREA SEMARANG CITY] In 2017 in the city of Semarang, the maternal mortality rate (MMR) was 88.3 per 100,000 live births (KH). The cause of AKI case was the delay in pregnancy detection and ANC implementation that was not up to standard. Good quality service provided by health workers will certainly increase community satisfaction. The purpose of this study was to determine the ANC $10 \mathrm{~T}$ service standard on the satisfaction of pregnant women at Tlogosari Kulon Public Health Center Semarang City. This type of research is an analytic observational with a cross sectional approach. Sampling was carried out using accidental sampling obtained as many as 55 TM III pregnant women. Methods of data analysis using descriptive statistical frequencies and chi-square test. The results showed that the $10 \mathrm{~T}$ ANC service standard was mostly carried out completely according to the $10 \mathrm{~T}$ standard, namely 43 pregnant women $(78.2 \%)$. The satisfaction of pregnant women at the time of conducting ANC examinations was that most of the pregnant women were satisfied with the services provided by the midwives, namely 44 pregnant women $(80 \%)$. There is a relationship between ANC $10 \mathrm{~T}$ service standards and satisfaction of pregnant women. In conclusion, the majority of services are carried out according to standards and mothers are satisfied.
\end{abstract}

Keywords: Maternal mortality rate, ANC 10 T service standards, Satisfaction of pregnant women.

\section{Pendahuluan}

Kota Semarang jumlah Angka Kematian Ibu (AKI) sebanyak 88,3 per 100.000 Kelahiran

\footnotetext{
*) Correspondence (Kharisma Rakhmah)

E-mail: kharismarakhmah03@gmail.com
}

Hidup (KH). AKI mengalami penurunan dari tahun sebelumnya yaitu 121,5 per $100.000 \mathrm{KH}$ pada tahun 2016 namun masih dikatakan masih cukup tinggi untuk nilai AKI. Kota Semarang merupakan penyumbang 4 besar terbanyak AKI 
di Jawa Tengah. Pada tahun 2015 di wilayah kerja Puskesmas Tlogosari Kulon merupakan penyumbang AKI 2 besar terbanyak di Kota Semarang (Dinkes Kota Semarang, 2017).

Terdapat kasus kematian ibu disebabkan penyakit jantung pada waktu masa nifasdi wilayah kerja Puskesmas Gending pada tanggal 11 Juni 2012. Setelah ditelusuri penyebabnya yaitu keterlambatan dalam deteksi dini komplikasi kehamilan dan didapatkan data bahwa pelaksanaan ANC belum sesuai standar (Puskesmas Gending Kabupaten Gresik, 2012).

Menurut hasil penelitian Kaparang, (2015) Faktor penyebab bidan tidak melakukan ANC terpadu sesuai standar karena beberapa faktor yaitu beban kerja yang diberikan terlalu banyak dan kurang tenaga kesehatan bidan bertugas dalam menjalankan program di Puskesmas. Seperti program gizi, program imunisasi, program Manajemen Terpadu Balita Sakit (MTBS) yang merupakan lintas sektor yang berkaitan dengan pemeriksaan kehamilan, kunjungan ibu hamil yang banyak.

Menurut pedoman pelayanan ANC terpadu yang diluncurkan oleh Kementerian Kesehatan RI (2010) seorang bidan harus melakukan pelayanaan sesuai standar $10 \mathrm{~T}$, seperti (Timbang berat badan dan ukur Tinggi badan, ukur Tekanan darah, nilai status gizi ukur Lingkar Lengan Atas (LiLA), ukur Tinggi Fundus Uteri (TFU) tentukan presentasi janin dan Denyut Jantung Janin (DJJ), skrining status imunisasi tetanus dan Berikan Imunisasi Tetanus Toksoid (TT) bila diperlukan, beri tablet tambah darah, periksa laboratorium (rutin dan khusus), tatalaksana/penanganan kasus, temu wicara. Tenaga kesehatan Bidan dalam melakukan pelayanan ANC terpadu $10 \mathrm{~T}$ bertujuan untuk memenuhi hak setiap ibu hamil untuk mendapatkan yang berkualitas sehingga mampu menjalani kehamilan dengan sehat, bersalin dengan selamat, dan melahirkan bayi yang sehat.

Kualitas pelayanan menurut Maulana (2011) bahwa kualitas merupakan pelayanan yang diharapkan dapat memaksimalkan suatu ukuran yang inklusif dari kesejahteraan klien. Penilaian kualitas pelayanan dilakukan melalui 3 pendekatan yaitu kualitas struktur, kualitas proses dan kualitas hasil. Untuk menjamin kualitas pelayanan maka diperlukan adanya kebijakan. Kebijakan tersebut diantaranya peningkatan kemampuan dan mutu pelayanan kesehatan, penetapan dan penerapan standar, peningkatan mutu sumber daya manusia, penyelenggaraan quality assurance, percepatan pelaksanaan akreditasi, peningkatan kerjasama serta koordinasi dan peningkatan peran serta masyarakat. Kualitas pelayanan yang baik dilakukan oleh tenaga kesehatan pastinya akan meningkatkan kepercayaan dan kepuasan masyarakat.

Kepuasan merupakan perasaan senang atau kecewa seseorang yang muncul setelah membandingkan antara persepsi atau kesannya terhadap kinerja atau hasil suatu produk dan harapan-harapannya. Kepuasan pasien berhubungan dengan mutu atau kualitas pelayanan puskesmas. Dengan mengetahui tingkat kepuasan pasien, manajemen puskesmas dapat melakukan peningkatan mutu pelayanan. Pengukuran kepuasan pasien bisa dinilai dengan 5 karakteristik yaitu reliability, assurance, tangibles, empathy, responsiveness (Nursalam, 2015).

Penelitian yang dilakukan oleh Davina Amalia (2018) menunjukkan hasil nilai signifikasi $(p=0,21)$ dan koefisien korelasi $(r=0,252)$. Penelitian ini menyimpulkan bahwa terdapat hubungan yang signifikan antara indeks kepuasan pasien tentang mutu pelayanan dimensi kehandalan dengan minat berobat kembali di RSD Kalisat Kabupaten Jember.

Upaya pemerintah melalui SK Menkes No 284/Menkes/SK/III/2004 menetapkan tentang buku Kesehatan Ibu dan Anak (KIA) sebagai alat pencatatan pelayanan kesehatan ibu dan anak sejak ibu hamil (pelayanan ANC), melahirkan dan selama nifas hingga bayi yang dilahirkan berusia 5 tahun, termasuk pelayanan $\mathrm{KB}$, imunisasi, gizi dan tumbuh kembang anak. Buku KIA sebagai pedoman sumber informasi untuk menambah pengetahuan untuk ibu hamil sebagai deteksi dini. Saat ini pemerintah telah meluncurkan program Buku KIA telah menyebarkan 5 juta eksemplar Buku KIA ke seluruh Kab/Kota di Indonesia (Kemenkes RI, 2017).

Upaya bidan dalam pelayanan bisa diterapkan melalui Continuity of Care yang dilakukan oleh bidan di Australia dimana terbukti meningkatkan hubungan bidan dengan klien, klien merasa lebih nyaman selama menghadapi proses kehamilan, persalinan, dan nifas. Serta meningkatkan kepuasan klien terhadap pelayanan kesehatan yang telah dilakukan (Williams, 2012). 
Peneliti melakukan study pendahuluan melakukan wawancara dengan bidan koordinasi Puskesmas Tlogosari Kulon terkait dengan kualitas pelayanan ANC pada ibu hamil yang meliputi sarana prasarana, tenaga kesehatan (bidan), pasien (ibu hamil). Data evaluasi yang didapatkan yaitu sarana prasarana terdapat 1 (satu) ruang ANC di puskesmas, pelayanan ANC dilakukan pada hari senin sampai sabtu. Tenaga kesehatan yaitu bidan yang bekerja di Puskesmas Tlogosari Kulon jumlahnya 8 orang bidan, pembagian pekerjaan bidan diruang KIA terdapat 3 bidan dan ruang Instalasi Gawat Darurat (IGD) terdapat 5 bidan setiap harinya. Bidan yang bertugas di ruang KIA mampu melayani ANC $10 \mathrm{~T}$ dengan baik sesuai dengan SOP. Pasien yaitu ibu hamil K4 yang memeriksakan kehamilannya di puskesmas dari bulan januari sampai dengan Agustus jumlahnya yaitu 796 ibu hamil. Proses pelayanan ANC dimulai ibu hamil menunggu antrian dari loket pendaftaran sampai mendapatkan pelayanan ANC diruang KIA. Bidan dalam proses memberikan pelayanan ANC pada setiap ibu hamil membutuhkan waktu kurang lebih 15 menit untuk mendapatkan kualitas pelayanan yang maksimal yaitu $10 \mathrm{~T}$.

Dari uraian tersebut, maka penulis tertarik untuk mengetahui hubungan standar pelayanan ANC $10 \mathrm{~T}$ terhadap kepuasan ibu hamil di wilayah kerja Puskesmas Tlogosari Kulon Kota Semarang.

\section{Metode}

Pengambilan sampel dilaksanakan dengan menggunakan accidental sampling dikarenakan pelayanan ANC dilakukan setiap hari dan tidak ada hari khusus untuk pelayanan ANC. Penelitian ini dilaksanakan mulai tanggal 20 September sampai 5 Oktober 2019 didapatkan sebanyak 55 ibu hamil, dimana mengambil responden yang kebetulan ada atau ibu hamil yang datang untuk periksa ANC di Puskesmas Tlogosari Kulon sesuai dengan konteks atau kriteria penelitian (ibu hamil TM 3, bersedia menjadi responden, ibu yang memeriksakan kehamilan di wilayah kerja puskesmas kota Semarang, menggunakan buku KIA 2015) maka sampel tersebut diambil dan langsung dijadikan sebagai sampel utama.

Jenis penelitian ini adalah penelitian observasional analitik dengan pendekatan cross sectional. Pengumpulan data dilakukan dengan menggunakan alat ukur kuesioner standar pelayanan ANC $10 \mathrm{~T}$ dan kepuasan ibu hamil. Metode analisis data menggunakan uji descriptive dan analitik.

\section{Hasil dan Pembahasan}

a. Standar pelayanan ANC $10 \mathrm{~T}$

Hasil penelitian dari 55 ibu hamil tentang standar pelayanan ANC $10 \mathrm{~T}$ yang dilakukan bidan sebagai berikut ini :

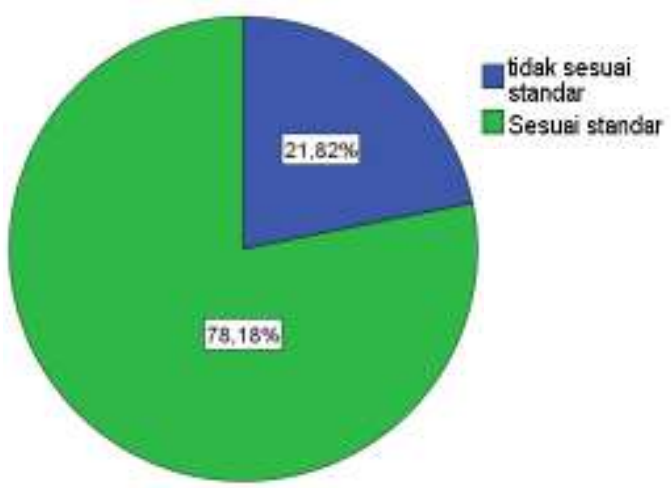

\section{Gambar 1 Standar pelayanan ANC $10 \mathrm{~T}$}

Berdasarkan gambar 1 dapat diketahui bahwa standar pelayanan ANC $10 \mathrm{~T}$ yang dilakukan bidan di Puskesmas Tlogosari kulon mayoritas pada kategori sesuai standar yaitu 43 ibu hamil $(78,2 \%)$ dan kategori tidak sesuai standar $<10 \mathrm{~T}$ yaitu $12 \mathrm{ibu}$ hamil $(21,8 \%)$. Bidan tidak melakukan sesuai standar dikarenakan beban kerja yang diberikan terlalu banyak misalnya program gizi, program imunisasi, programManajemen Terpadu Balita Sakit (MTBS) dan banyaknya kunjungan ibu hamil yang memeriksakan kehamilannya.

Penelitian ini sejalan dengan penelitian yang dilakukan oleh Bundarini (2019) tentang gambaran kelengkapan antenatal care terpadu di Puskesmas Tepus II Gunungkidul. Hasil penelitiannya menunjukkan ibu hamil yang memperoleh pelayanan antenatal standar $10 \mathrm{~T}$ sebagian besar sesuai stndar yaitu 144 orang (72\%).

Penelitian yang dilakukan oleh Mumu (2015) menyatakan bahwa untuk meningkatkan kepatuhan bidan dalam memberikan pelayanan antenatal maka bidan harus memberikan pelayanan sesuai dengan Standar Operasional Prosedur (SOP) sehingga perlu dilakukan monitoring terhadap bidan selama memberikan pelayanan antenatal dengan harapan dapat meningkatkan kompetensi bidan dalam memberikan pelayanan antenatal. SOP 
pelayanan terhadap kepuasan pasien berupa assurance yaitu memberikan jaminan pelayanan kesehatan yang berupa sikap yang meyakinkan, motivasi yang ditunjukkan, kesesuaian dalam berbagai pelayanan kesehatan yang tentunya memberikan suatu nilai tersendiri yang dapat diyakini oleh setiap pasien (Sari Devy, 2014)

Pelayanan ANC di puskesmas Tlogosari Kulon sudah disediakan standar operasional prosedur (SOP) yang baku. Penerapan SOP dalam pelayanan ANC oleh bidan akan mendukung terwujudnya kualitas pelayanan ANC yang baik.

Kualitas pelayanan menurut Maulana (2011) menjelaskan tentang kualitas merupakan pelayanan yang diharapkan dapat memaksimalkan suatu ukuran yang inklusif dari kesejahteraan klien. Penilaian kualitas dilakukan melalui 3 pendekatan yaitu kualitas struktur, kualitas proses dan kualitas hasil. Untuk menjamin kualitas pelayanan maka diperlukan adanya kebijakan.

Menurut hasil penelitian Kaparang (2015) faktor penyebab bidan tidak melakukan ANC terpadu sesuai standar karena beberapa faktor yaitu beban kerja yang diberikan terlalu banyak, kurang tenaga kesehatan bidan bertugas dalam menjalankan program di Puskesmas, seperti program gizi, program imunisasi, program Manajemen Terpadu Balita Sakit (MTBS) yang merupakan lintas sektor yang berkaitan dengan pemeriksaan kehamilan, banyaknya kunjungan ibu hamil yang memeriksakan kehamilannya.

Tabel 1 Standar pelayanan ANC $10 \mathrm{~T}$

\begin{tabular}{lc}
\hline \multicolumn{1}{c}{ Standar pelayanan ANC 10 T } & Tidak dilakukan \\
\hline Penimbangan berat badan ukur tinggi badan & 0 \\
Pengukuran tekanan darah & 0 \\
Pengukuran Lingkar Lengan Atas (LiLA) & 6 \\
Pengukuran tinggi rahim (tinggi fundus uteri). & 0 \\
Penentuan presentasi janin dan penilaian Denyut Jantung Janin (DJJ) & 0 \\
Skrining imunisasi TT/diberikan bila perlu & 2 \\
Pemberian tablet tambahdarah (FE) & 4 \\
Pemeriksaan laboratorium & 2 \\
Pelaksanaan temu wicara/konseling & 6 \\
Tatalaksana kasus & 0 \\
\hline
\end{tabular}

Dari hasil tabel 1 kuisioner penelitian tentang standar pelayanan ANC $10 \mathrm{~T}$ dengan kategori tidak tidak sesuai standar $<10 \mathrm{~T}$ yang mayoritas tidak dilakukan pelayanan oleh bidan yaitu pengukuran Lingkar Lengan Atas (LiLA) ibu yaitu 6 ibu hamil, konseling tentang kehamilan TM III yaitu 6 ibu hamil serta tidak dilakukan pengukuran LiLA dan konseling tentang kehamilan TM III yaitu 3 ibu hamil. Jumlah 0 yaitu semua (55 ibu hamil) dilakukan pelayanan penimbangan berat badan ukur tinggi badan, pengukuran tekanan darah, pengukuran tinggi rahim (tinggi fundus uteri), penentuan presentasi janin dan penilaian denyut jantung janin (djj), tatalaksana kasus.

Pada penelitian ini untuk standar pelayanan ANC 10 T mayoritas tidak dilakukan pelayanan oleh bidan yaitu pengukuran Lingkar Lengan Atas (LiLA) dan konseling yaitu 6 ibu hamil. Pada pengukuran LilA jika $<23,5 \mathrm{~cm}$, maka menunjukkan deteksi ibu hamil menderita
Kurang Energi Kronis (KEK) dan berisiko melahirkan Bayi Lahir Rendah (BBLR). Konseling yang dilakukan oleh tenaga kesehatan pada ibu hamil mengenai perawatan kehamilan, pencegahan kelainan bawaan, persalinan dan Inisiasi Menyusui Dini (IMD). Tujuan tenaga kesehatan melakukan standar pelayanan ANC untuk memantau dan meningkatkan kesehatan ibu dan janin(Kemenkes RI, 2015).

Pada pengukuran LiLA mayoritas dilakukan sebanyak 51 ibu (92,7\%), dimana hasil ini menunjukkan bahwa kinerja bidan sudah banyak melakukan pelayanan sesuai standar.

Menurut penelitian yang dilakukan oleh Gapmelezy (2018) di Wilayah Kerja Puskesmas Sumber Sari Bantul Kota Metro menjelaskan bahwa adanya bidan yang tidak melakukan pemeriksaan LiLA tersebut dapat dimungkinkan karena kondisi ibu yang menurut bidan sudah termasuk dalam kategori 
normal atau status gizi yang baik sehingga mereka tidak melakukan pengukuran LiLA.

Hasil penelitian kualitatif yang dilakukan oleh Marniyati (2016) menurut pernyataan yang diberikan oleh Kepala Puskesmas bahwa bidan telah melaksanakan pelayanan antenatal sesuai standar walaupun belum dilaksanakan secara optimal terutama dalam anamnesis dan konseling dikarenakan membutuhkan waktu yang cukup lama. Selain itu, ada pemeriksaan fisik yang sulit untuk dilakukan dikarenakan alat yang rusak yaitu pemeriksaan LiLA dan denyut jantung janin menggunakan doppler portable. Kemudian bidan juga mengalami kesulitan dalam pencatatan dan pelaporan pelayanan antenatal dikarenakan banyak format pencatatan dan pelaporan yang harus diisi.

Menurut penelitian yang dilakukan oleh Demny (2013) keterbatasan fasilitas dan keadaan alat ANC yang rusak menyebabkan suatu permasalahan yang berdampak dengan rendahnya mutu pelayanan antenatal care. Hasil penelitiannya menunjukkan bahwa ada hubungan antara hubungan interpersonal dengan mutu pelayanan dan responden yang menyatakan kurang pada ketersediaan fasilitas dan peralatan antenatal care adalah $21,1 \%$ responden.

b. Kepuasan ibu hamil

Hasil penelitian dari 55 ibu hamil tentang kepuasan ibu hamil setelah dilakukan pelayanan oleh bidan sebagai berikut ini :

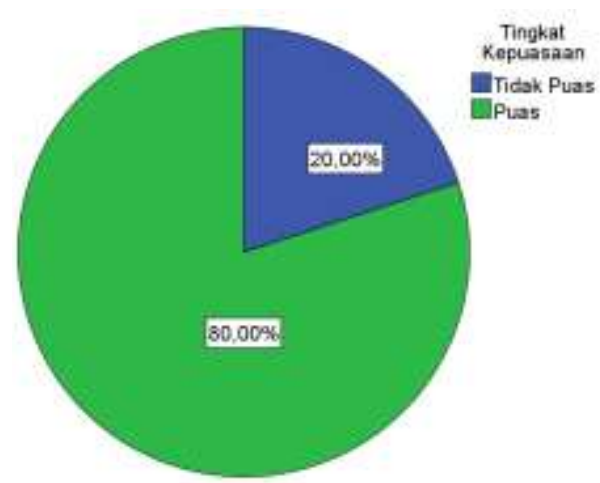

Gambar 2 Kepuasan ibu hamil

Gambar 2 berikut ini dapat menunjukkan bahwa kepuasan ibu hamil di Puskesmas Tlogosari kulon mayoritas pada kategori puas yaitu 44 ibu hamil (80\%) dan kategori tidak puas yaitu 11 ibu hamil (20\%).

Penelitian ini sejalan dengan hasil penelitian Rahayu (2013) menjelaskan bahwa tingkat kepuasan ibu hamil di Puskesmas
Karanganyar Kabupaten Purbalingga Tahun 2013 sebagian besar adalah puas yaitu 52 orang (70,3\%).

Tabel 2 Aspek kepuasan ibu hamil

\begin{tabular}{cc}
\hline $\begin{array}{c}\text { Aspek kepuasan } \\
\text { ibu hamil }\end{array}$ & Score (Mean) \\
\hline Tangibles & 101 \\
Reliability & 100,3 \\
Responsive & 102,5 \\
Assurance & 101,6 \\
Empaty & 97,6 \\
\hline
\end{tabular}

Dari hasil Tabel 2 kuisioner penelitian tentang kepuasan ibu hamil dengan kategori puas disebabkan karakter bidan adalah responsive dengan score paling banyak yaitu 102,5. Sedangkan kategori tidak puas disebabkan karakteristik bidan adalah empaty ke ibu hamil dalam proses pelayanan dengan score paling sedikit yaitu 97,6.

Kepuasan merupakan perasaan senang atau kecewa seseorang yang muncul setelah membandingkan antara persepsi atau kesannya terhadap kinerja atau hasil suatu produk dan harapan-harapannya. Kepuasan pasien berhubugan dengan mutu atau kualitas pelayanan puskesmas dengan mengetahui tingkat kepuasan pasien, manajemen puskesmas dapat melakukan peningkatan mutu pelayanan. Pengukuran kepuasan pasien bisa dinilai dengan 5 karakteristik yaitu keandalan (reliability), jaminan (assurance), kenyataan (tangibles), empati (empathy), tanggung jawab (responsiveness) (Nursalam, 2015).

Tingkat kepuasan pasien merupakan hal yang sudah mulai diidentifikasi dalam pelayanan bidang kesehatan karena tingkat kepuasan yang tinggi akan sangat mempengaruhi alasan masyarakat membuat pilihan dan tetap menggunakan jasa pelayanan kesehatan (Rumintang, 2015).

Beberapa ibu hamil merasa puas meskipun pelayanan yang diberikan tidak sesuai standar < 10 T. Hal ini kemungkinan disebabkan kecekatan bidan dalam memberikan pelayanan (responsive) dengan score paling tinggi ibu hamil mersa puas yaitu 102,5. Seperti halnya penelitian di klinik Pratama Niar Kabupaten Deli Serdang dari 39 ibu hamil, 36 diantaranya merasa puas pada saat bidan memberikan informasi yang tidak berbelit - belit dan mudah dimengerti (Siregar et al., 2018). 
Menurut penelitian Jati (2014) Hasil pengujian menunjukkan persepsi empati mempunyai hubungan dengan kepuasan ibu hamil, terbukti dengan nilai Chi-Square sebesar 43,020 dengan nilai p-value sebesar 0,000 $(\mathrm{p}<0.05)$.

Beberapa ibu hamil merasa puas diantaranya kemungkinan disebabkan pasien merasa aman di priksa oleh bidan dan percaya mampu melayani pasien dengan baik (assurance). Aspek assurance (jaminan) merupakan salah satu aspek kualitas pelayanan yang berhubungan dengan kemampuan dalam menanamkan kepercayaan dan keyakinan pasien. Dalam hal ini meliputi kemampuan petugas atas pengetahuan yang tepat, terampil dalam memberikan pelayanan dan menjamin keamanan pasien yang menimbulkan pasien merasa puas dengan pelayanan yang di berikan (Mandias, 2013).
Beberapa ibu hamil merasa puas diantaranya disebabkan penampilan bidan yang berpakaian rapih dan bersih (tangibles). Penelitian ini sejalan dengan hasil penelitian yang dilakukan Sari (2017) di Puskesmas Temon II Kulon Progo Tahun 2017, menyimpulkan bahwa ibu hamil yang merasa puas sebanyak 51 responden $(98,1 \%)$ dan 1 responden $(1,9 \%)$ merasa tidak puas dengan bukti fisik (tangibles) dalam pelayanan antenatal care terintegrasi di Puskesmas Temon II Kulon Progo.

Beberapa ibu hamil merasa puas diantaranya disebabkan kehandandalan bidan selalu siap melayani pasien setiap saat (reliability). Salah satu faktor penyebab meningkatnya kepuasan pasien yaitu reliability. Reliability merupakan keandalan dan keterampilan petugas kesehatan dalam memberi pelayanan serta menyelenggarakan pelayanan (Maulana, 2011).

c. Hubunganstandar pelayanan ANC $10 \mathrm{~T}$ terhadap kepuasan pasien.

Tabel 3

Hubungan standar pelayanan $10 \mathrm{~T}$ terhadap kepuasan ibu hamil

\begin{tabular}{|c|c|c|c|c|c|c|c|}
\hline \multirow{3}{*}{ Standar pelayanan ANC $10 \mathrm{~T}$} & \multicolumn{6}{|c|}{ Tingkat Kepuasan Ibu Hamil } & \multirow{3}{*}{$p$-value } \\
\hline & \multicolumn{2}{|c|}{ Tidak puas } & \multicolumn{2}{|c|}{ Puas } & \multicolumn{2}{|c|}{ Total } & \\
\hline & $\mathbf{n}$ & $\%$ & $\mathbf{n}$ & $\%$ & $\mathbf{n}$ & $\%$ & \\
\hline Tidak sesuai standar $<10 \mathrm{~T}$ & 6 & 10,9 & 6 & 10,9 & 12 & 100 & 0,008 \\
\hline Sesuai standar & 5 & 9,1 & 38 & 69,1 & 43 & & \\
\hline
\end{tabular}

Keterangan : * Uji Fisher's Exact Test

Berdasarkan Tabel 3 dapat diketahui bahwa standar pelayanan ANC $10 \mathrm{~T}$ yang dilakukan bidan dengan kategorik tidak sesuai standar $<10 \mathrm{~T}$ yang merasa tidak puas yaitu 6 ibu hamil $(10,9 \%)$ dan merasa puas yaitu 6 ibu hamil (10,9\%). Sedangkan pelayanan ANC yang dilakukan bidan dengan kategorik sesuai standar mayoritas merasa puas yaitu $38 \mathrm{ibu}$ hamil $(69,1 \%)$ dan merasa tidak puas yaitu $5 \mathrm{ibu}$ hamil $(9,1 \%)$.

Hasil perhitungan dengan Chi- Square Test diperoleh nilai $\mathrm{P}=0,008(\mathrm{P}<0,05)$, maka $\mathrm{Ho}$ ditolak dan Ha diterima. Hal ini menunjukkan hasil bahwa ada hubungan yang signifikan antara standar pelayanan ANC $10 \mathrm{~T}$ terhadap kepuasan ibu hamil di wilayah kerja Puskesmas Tlogosari Kulon Kota Semarang.

Menurut hasil penelitian Rahayu (2013) kualitas pelayanan ANC di Puskesmas Karanganyar Kabupaten Purbalingga Tahun 2013 terdapat hubungan kualitas pelayanan Antenatal care (ANC) dengan tingkat kepuasan ibu hamil di Puskesmas Karanganyar Kabupaten Purbalingga tahun $2013(\mathrm{p}=0,000)$ menunjukkan bahwa kualitas pelayanan yang semakin baik akan diikuti dengan meningkatnya kepuasan ibu hamil.

Hasil penelitian yang dilakukan Amatiria (2017) Diketahui bahwa seluruh responden yaitu sebanyak $50 \quad(64,9 \%)$ responden menyatakan bahwa kualitas pelayanan yang diberikan oleh RS Graha Husada sudah dilaksanakan dengan baik, sedangkan 27 responden $(35,1 \%)$ menyatakan kualitas pelayanan yang diberikan oleh RS Graha Husada kurang. Diketahui bahwa seluruh responden yaitu sebanyak $44(57,1 \%)$ responden menyatakan puas, sedangkan sebanyak 33 responden $(42,9 \%)$ menyatakan tidak puas. Ada hubungan signifikan antara Kualitas Pelayanan ANC dengan Kepuasan Pasien Dirumah Sakit Graha Husada Bandar Lampung Tahun 2014 nilai $\mathrm{p}$ value $<0,05)$. 
Menurut hasil penelitian yang di lakukan di RS Achimota negara Ghana oleh Mensah (2018) Menjelaskan bahwa hampir semua $(91,81 \%)$ responden puas dengan layanan ANC, obat-obatan, pencegahan dan pengendalian infeksi dan beberapa pedoman tersedia di fasilitas. pengambilan riwayat, penyelidikan laboratorium dan klinis, pendidikan kesehatan dan pemeriksaan fisik dari kepala hingga kaki dilakukan pada hampir semua responden kemudian dikaitkan dengan kepuasan pasien didapatkan ( $\mathrm{p}=0,000)$ yang menunjukkan ada hubungan kualitas pelayanan yang baik dengan meningkatnya kepuasan pasien.

Menurut penelitian yang dilakukan di klinik daerah Nallur Depkes, Jaffna oleh Dissanayake (2018) menunjukan bahwa $224 \mathrm{ibu}$ hamil 51,8\% merasa puas dengan kualitas pelayanan antenatal secara keseluruhan. Ibu merasa puas dikarenakan puas terhadap kondisi tempat duduk yang tersedia, waktu tunggu yang efisien, keadaan lingkungan yang bersih, serta dukungan dan sikap yang diberikan oleh tenaga kesehatan.

Keterbatasan penelitian ini yaitu kuesioner yang digunakan dalam penelitian ini adalah kuesioner tertutup sehingga responden hanya bisa menjawab puas atau tidakpuas, dilakukan atau tidak dilakukan. Keterbatasan waktu penelitian dalam lamanya melakukan penelitian sehingga keterbatasan dalam jumlah reponden.

\section{Simpulan dan Saran}

Simpulan dalam penelitian dari hasil analisa terhadap standar pelayanan ANC $10 \mathrm{~T}$ di wilayah kerja Puskesmas Tlogosari Kulon Kota Semarang sebagian besar dilakukan secara lengkap sesuai standar $10 \mathrm{~T}$ yaitu 43 ibu hamil $(78,2 \%)$. Kepuasan ibu hamil pada waktu melakukan pemeriksaan hamil di wilayah kerja Puskesmas Tlogosari Kulon Kota Semarang sebagian besar ibu hamil merasa puas dengan pelayanan yang diberikan oleh bidan yaitu 44 ibu hamil (80\%) .Ada hubungan standar pelayanan ANC $10 \mathrm{~T}$ terhadap kepuasan ibu hamil di wilayah kerja Puskesmas Tlogosari Kulon Kota Semarang.

Saran dalam penelitian dari hasil analisa terhadap upaya peningkatan kebijakan program SOP dengan memonitoring, perlu adanya penambahan SDM tenaga kesehatan bidan, pengurangan beban kerja SDM (bidan) diluar tupoksi, pelayanan standar ANC secara komprehesif (misalkan harus kolaborasi dengan dokter gigi, dokter umum, bagian gizi dan lainlain) serta evaluasi pelayanan ANC $10 \mathrm{~T}$. Bagi tenaga kesehatan Bidan yaitu perlu meningkatkan kepatuhan dalam melakukan pelayanan ANC $10 \mathrm{~T}$ sesuai standar pada setiap ibu hamil, bidan harus manajemen waktu dengan baik dalam melakukan standar pelayanan ANC $10 \mathrm{~T}$.

\section{Ucapan Terima Kasih}

Terima kasih disampaikan kepada Puskesmas Tlogoari Kulon Kota Semarang dan Fakultas Kedokteran Prodi Kebidanan Unissula yang telah memberikan dukungannya selama proses penelitian ini sehingga penelitian ini selesai dengan baik.

\section{Daftar Pustaka}

Amatiria, G. (2017). Hubungan Kualitas Pelayanan Antenatal Care (ANC) Dengan Kepuasan Pasien. Jurnal Ilmiah Keperawatan Sai Betik, 12(1), 106-111. Retrieved from https:/ / ejurnal.poltekkes-

tjk.ac.id/index.php/JKEP/article/view/ 366/338\%0Ahttps:/ / ejurnal.poltekkestjk.ac.id/index.php/JKEP/article/view/ 366

Bundarini, B., \& Fitriahadi, E. (2019). Gambaran Kelengkapan Antenatal Care Terpadu Di Puskesmas Tepus II Gunungkidul. Jurnal SMART Kebidanan, 6(2), 70. https://doi.org/10.34310/sjkb.v6i2.272

Davina Amalia. (2018). Hubungan Indeks Kepuasan Pasien Tentang Mutu Pelayanan Dimensi Kehandalan Dengan Minat Berobat Kembali Di RSD Kalisa Kabupaten Jember.6.

Demny. (2013). Analisis Mutu Pelayanan Antenatal Care Di Puskesmas Wonrely Kabupaten Maluku Barat Daya Provinsi Maluku Tahun 2012.

Dinkes Kota Semarang. (2017). Profil Kesehatan Kota Semarang. Semarang: Dinkes Kota Semarang.

Dissanayake. (2018). Satisfaction of pregnant mothers on institutional infrastructure facilities in primary health care centers in Nallur MOH area. Jaffna, (August), 2018.

Gapmelezy, E. (2018). Gambaran Kualitas Pelayanan Antenatal Di Wilayah Kerja Puskesmas Sumber Sari Bantul Kota Metro.3(2).

Jati, S., Sriatmi, A., \& Kusumastuti, M. (2014). Analisis Hubungan Persepsi Mutu 
Pelayanan Antenatal Terhadap Kepuasan Ibu Hamil Di Puskesmas Bangetayu Kota Semarang Tahun 2014. Jurnal Kesehatan Masyarakat (e-Journal),2(4), 276-282.

Kaparang, M. J., Widjanarko, B., \& Purnami, C. T. (2015). Mutu Pelayanan Asuhan Antenatal Care oleh Bidan Pasca Pelatihan ANC Terpadu di Propinsi Sulawesi Tengah. Manajemen Kesehatan Indonesia.03(02), 114-121.

Kemenkes RI. (2015). Buku Kesehatan Ibu dan Anak. Jakarta: Kementrian Kesehatan.

Kemenkes RI. (2017). Optimalisasi Pemanfaatan Buku KIA. Retrieved from https://dinkes.bantenprov.go.id/read/b erita/1004/OPTIMALISASIPEMANFAATAN-BUKU-KIA.html. Diakses. 20 Mei 2019

Kementerian Kesehatan RI. (2010). Pedoman Pelayanan Antenatal Terpadu. Jakarta: Kementerian Kesehatan RI.

Mandias. (2013). Analisis Hubungan Pelayanan Kesehatan Terhadap Kepuasan Pasien Rawat Inap RSUP Prof Dr. R. D. Kandou Manado.

Marniyati, L. (2016). Pelayanan Antenatal Berkualitas dalam Meningkatkan Deteksi Risiko Tinggi pada Ibu Hamil oleh Tenaga Kesehatan di Puskesmas Sako, Sosial, Sei Baung dan Sei Selincah di Kota Palembang. Januari, 3(1), 355-362.

Maulana. (2011). Penilaian Kepuasan Ibu Hamil Terhadap Mutu Layanan Antenatal Dalam Kaitannya Dengan Kepatuhan Dan Karakteristik Bidan Di Puskesmas Se Kota Jambi Tahun 2011.

Mensah, G. A. (2018). Assessment of Quality of Care among Pregnant Women in the Achimota Hospital. (10332207), 1-115.
Mumu, L. J., Kandou, G. D., \& Doda, D. V. (2015). Analisis Faktor-Faktor Yang Berhubungan Dengan Kepuasan Pasien di Poliklinik Penyakit Dalam RSUP Prof. Dr. R. D . Kandou Manado Clinic of Internal Medicine Department of RSUP Prof. Dr. R . $D$. Kandou. Jurnal Unsrat, 1. Retrieved from

https://ejournal.unsrat.ac.id/index.php /jikmu/article/view/7460

Nursalam. (2015). Manajemen Keperawatan. Jakarta. Jakarta: Salemba Medika.

Puskesmas Gending Kabupaten Gresik. (2012). Data Dokumentasi Asuhan Kebidanan . Gresik.

Rahayu, Y. P. (2013). Gambaran Tingkat Kepuasan Ibu Hamil Tentang Mutu Pelayanan Anc Di Puskesmas Jambu Burung Kabupaten Banjar. Journal of Chemical Information and Modeling, 53(9), 1689-1699.

Rumintang, B. I. (2015).Bagaimana Tingkat Kepuasan Ibu hamil pada Pelayanan Antenatal? Hasil Penerapan Model Pelayanan Antenatal Kontinu.Link, 11.

Sari, N. (2017). Gambaran Kepuasan Ibu Hamil Pada Pelayanan Antenatal Care Terintegrasi Di Puskesmas Temon II Kulon Progo Tahun 2017.

Siregar, M., Harianja, N. Y. F., Oleh, A. N. C., Di, B., Kerja, W., \& Ngoresan, P. (2018). Di Klinik Pratama Niar Kabupaten Deli Serdang Tahun 2018. Jurnal Ilmiah PANNMED, 13(1), 37-42.

Williams, et al. (2012). Mothers' Views of Caseload Midwefer and the Value of Continuity of Care at an Australian Regional Hospital.2, 615621. 